\title{
UJI EFEKTIVITAS BEBERAPA JENIS PERANGKAP TERHADAP KUMBANG TANDUK (Oryctes rhinoceros L.) (COLEOPTERA; SCARABAEIDAE)
}

\author{
Effectivity of Some Types of Traps on the Horn Beetle (Oryctes rhinoceros L.) \\ (Coleoptera: Scarabaeidae)
}

\author{
Rieske Luhukay ${ }^{1, *}$, Betty Sahetapy ${ }^{2}$, Aminudin Umasangadji² $^{2}$ \\ ${ }^{1}$ Program Studi Agroekoteknologi, Jurusan Budidaya Pertanian, Fakultas Pertanian, Universitas Pattimura \\ ${ }^{2}$ Jurusan Budidaya Pertanian, Fakultas Pertanian, Universitas Pattimura \\ J1. Ir. M. Putuhena, Kampus Poka, Ambon 97233 \\ * Penulis Korespondensi: E-mail: rieskeluhukay@gmail.com
}

\begin{abstract}
The objective of this study was to determine the types of traps that were effective in trapping horn beetles (O. rhinoceros L.). The research was conducted in Latuhalat Village, Nusaniwe District, Ambon Municipality, from September till November 2016. The treatment consisted of light trap, pheromone trap and pheromone and light trap. Observations were done on the number of imago of O. rhinoceros L. trapped and its sex ratio on each treatment. The results showed that pheromone trap was the most effective trap on $O$. rhinoceros $L$.
\end{abstract}

Keywords: coconut, O. rhinoceros L., traps, pheromones, light

\begin{abstract}
ABSTRAK
Penelitian ini bertujuan untuk mengetahui jenis perangkap yang efektif dalam memerangkap kumbang tanduk $(O$. rhinoceros L.). Penelitian ini dilaksanakan di Desa Latuhalat, Kecamatan Nusaniwe, Kota Ambon yang berlangsung dari bulan September sampai November 2016. Perlakuan jenis perangkap yaitu perangkap dengan lampu; perangkap dengan feromon; perangkap dengan feromon dan lampu. Data yang diamati adalah jumlah tangkapan imago $O$. rhinoceros L. tiap perlakuan, jumlah tangkapan imago O. rhinoceros L. jantan dan betina tiap perlakuan. Hasil penelitian menunjukan bahwa jenis perangkap dengan feromon merupakan perangkap yang paling efektif terhadap $O$. rhinoceros L.
\end{abstract}

Kata kunci: Kelapa, O. rhinoceros L., perangkap, feromon, lampu

\section{PENDAHULUAN}

Kelapa (Cocos nucifera L.) merupakan tanaman perkebunan berupa pohon berbatang lurus dari famili Palmae. Kelapa disebut juga tanaman serbaguna karena seluruh bagian tanaman seperti akar, batang, daun dan buahnya dapat dimanfaatkan untuk kebutuhan industri maupun rumah tangga (Setyamidjaja, 2000).

Di Indonesia kelapa menjadi salah satu komoditi tanaman perkebunan penting selain kakao, kelapa sawit, karet, tebu dan kopi. Berdasarkan data Direktorat Jendral Perkebunan tahun 2015, produksi kelapa di Indonesia pada tahun 2011 sebesar 0,84 ton/ha, tahun 2012 sebesar 0,84 ton/ha, tahun 2013 sebesar 0,83 ton/ha, tahun 2014 sebesar 0,83 ton/ha, dan tahun 2015 sebesar 0,83 ton/ha (Direktorat Jendral Pekebunan, 2015). Berdasarkan data Dinas Statistik Daerah Tingkat I Maluku tahun 2016, produksi kelapa di Maluku tahun 2011 sebesar 79.723 ton, tahun 2012 sebesar 123.366 ton, tahun 2013 sebesar 95.992 ton, tahun 2014 sebesar 100.459 ton, dan tahun 2015 sebesar 96.534 ton (Badan Pusat Statistik, 2016).
Banyak faktor yang mempengaruhi sehingga produksi kelapa berfluktuasi dari tahun ke tahun, salah satu faktor yaitu serangan hama tanaman. Kumbang tanduk (Oryctes rhinoceros L.) merupakan salah satu hama yang paling merusak dan serangannya hampir di seluruh perkebunan kelapa di Indonesia (Lekahena, 2013). O. rhinoceros L. termasuk serangga nokturnal dimana aktif pada malam hari dan tertarik pada cahaya. Imago $O$. rhinoceros $\mathrm{L}$. menggerek pucuk kelapa pada bagian yang lunak dan mengandung air, dengan demikian pada waktu daun membuka akan berbentuk seperti kipas, pelepah daun menjadi terhambat pertumbuhannya atau mati karena patah setelah daun mulai membuka, tidak terdapat pucuk baru karena kumbang menyerang dan merusak pada bagian penting yakni titik tumbuh. Apabila terjadi serangan yang berat dapat menyebabkan tanaman kelapa menjadi mati (Kartasapoetra, 1993). Menurut Wibawanti (2013), dengan rerataan jumlah guntingan 0,25-1,50 per pelepah dapat menyebabkan penurunan produksi buah $10-53 \%$. 
Usaha pengendalian $O$. rhinoceros L. dapat dilakukan secara kultur teknis dengan menebang tanaman yang sudah mati kemudian kayunya dimanfaatkan atau dapat ditumpuk dan dibakar, bertujuan agar tidak menjadi tempat berkembangbiak dari O. rhinoceros L.. Pengendalian secara biologi dengan menggunakan jamur Metarhizium anisopliae dan virus Baculovirus oryctes. Pengendalian secara nabati dengan pemanfaatan serbuk mimba (Hosang dan Salim, 2014).

Insektisida sintetik juga digunakan untuk mengendalikan serangga ini, misalnya memberikan Hepta chlor $10 \mathrm{G}$, sevin 85, BHC dan aldrin $40 \%$ WP (Setyamidjaja, 2000). Menurut Winarno (1992) dan Untung (1993), penggunaan insektisida dapat menyebabkan pencemaran lingkungan, terbunuhnya makhluk hidup yang bukan sasaran, resistensi dan resurjensi hama. Oleh karena itu, perlu diupayakan suatu metode pengendalian yang aman.

Metode aman lainnya untuk pengendalian $O$. rhinoceros L. dan mendukung kegiatan PHT yaitu penggunaan perangkap feromon (Ethyl 4methyloctanoate) (Hosang dan Salim 2014). Ethyl 4methyloctanoate merupakan senyawa feromon agregasi yang dihasilkan oleh imago $O$. rhinoceros L. jantan (Hallett et al., 1995; Morin et al., 1996). Metode sintesis dari feromon agregasi $O$. rhinoceros $\mathrm{L}$. telah dikembangkan (Bedford, 2014) dan sekarang tersedia dalam kemasan siap pakai dimana formulasi feromon akan menguap secara perlahan untuk menarik $O$. rhinoceros L. ke perangkap. Satu kemasan feromon agregasi sintetik (Ethyl 4-methyloctanoate) mampu bertahan tiga bulan di lapangan dengan tingkat keampuhan dalam memerangkap $O$. rhinoceros L. mencapai 95\% (Widyanto et al., 2014). Pemanfaatan perangkap feromon dalam pengendalian $O$. rhinoceros $\mathrm{L}$. sudah dilakukan oleh beberapa negara antara lain Filipina, Malaysia, Srilanka, India, Thailand dan Indonesia (Alouw, 2007).

Dalam penelitian ini akan diuji keefektivitasan dari beberapa jenis perangkap terhadap kumbang tanduk (O. rhinoceros L.), yang didasarkan dengan pemanfaatan feromon dan sifat serangga yang termasuk serangga noktunal. Penelitian ini bertujuan untuk mengetahui jenis perangkap yang efektif dalam memerangkap kumbang tanduk (O. rhinoceros L.).

\section{METODE PENELITIAN}

Penelitian dilaksanakan di Desa Latuhalat, Kecamatan Nusaniwe, Kota Ambon yang berlangsung dari bulan September-November 2016. Penelitian dilakukan pada lahan petani yang ditanami kelapa.

Bahan yang digunakan dalam penelitian ini adalah feromon agregasi sintetik (Ethyl 4methyloctanoate), lampu pijar (chiyoda 40 watt), ember plastik (ukuran 6 liter), lem, kabel, steker lampu, fitting lampu, kayu, paku, tali, kawat, wadah plastik, alkohol $70 \%$, jarum pentul dan label. Alat yang digunakan adalah meteran, gergaji, palu, pisau, obeng, thermometer,
Global Positioning System (GPS), alat suntik, alat tulis dan kamera.

Pada penelitian ini diuji tiga jenis perangkap terhadap hama $O$. rhinoceros $\mathrm{L}$. yaitu perangkap dengan lampu, perangkap dengan feromon, perangkap dengan feromon dan lampu. Masing-masing perlakuan diulang sebanyak empat kali, dengan demikian jumlah seluruh satuan percobaan adalah 12 satuan percobaan.

\section{Pelaksanaan Penelitian}

Survei lokasi penelitian dengan tujuan untuk mengetahui keadaan lokasi yang akan dijadikan sebagai tempat pelaksanaan penelitian.

Pembuatan perangkap: a) Perangkap dengan lampu, terdiri dari dua bagian yaitu (1) Lampu pijar, digantung pada bagian atas ember. (2) Ember plastik sebagai perangkap. Tutup ember dilepas, pada bagian dalam ember dioleskan lem dan dasar ember dibuat empat lubang (diameter $2 \mathrm{~mm}$ ) untuk pembuangan air hujan; b) Perangkap dengan feromon, terdiri dari dua bagian yaitu (1) Ember plastik sebagai perangkap. Tutup ember dilubangi sebanyak lima lubang (diameter $55 \mathrm{~mm}$ ) diletakan terbalik, pada dasar ember plastik dibuat 4 lubang (diameter $2 \mathrm{~mm}$ ) untuk pembuangan air hujan. (2) Feromon agregasi sintetik dikeluarkan dari kemasan, dililit pada kawat kecil sepanjang $10 \mathrm{~cm}$ dan dikaitkan pada tutup ember plastik yang diletakan terbalik; Perangkap dengan feromon dan lampu, terdiri dari tiga bagian yaitu (1) Ember plastik sebagai perangkap. Tutup ember dilubangi sebanyak lima lubang (diameter $55 \mathrm{~mm}$ ) diletakan terbalik, pada dasar ember plastik dibuat empat lubang (diameter $2 \mathrm{~mm}$ ) untuk pembuangan air hujan. (2) Feromon agregasi sintetik dikeluarkan dari kemasan, dililit pada kawat kecil sepanjang $10 \mathrm{~cm}$ dan dikaitkan pada tutup ember plastik yang diletakan terbalik. (3) Lampu pijar digantung pada bagian atas ember. Ketiga jenis perangkap digantung pada ketinggian $4 \mathrm{~m}$ dengan jarak antar perangkap $250 \mathrm{~m}$.

\section{Pengamatan}

Populasi imago kumbang tanduk (O. rhinoceros L.). Pengamatan dilakukan 7 hari setelah pemasangan perangkap selama 2 bulan dan dilakukan pada pukul 09.00-14.00 WIT. Sampel diperoleh dengan cara mengambil kumbang yang tertangkap pada masingmasing perlakuan.

Tangkapan imago kumbang tanduk (O. rhinoceros L.) jantan dan betina. Pengamatan dilakukan di laboratorium setelah sampel diperoleh dengan mengamati ciri-ciri fisik setiap imago O. rhinoceros L. yang tertangkap tiap perlakuan dengan ciri-ciri pada literatur Menon et al (1958) dan Kalshoven (1981).

Data yang diperoleh dilakukan tabulasi dan dihitung rata-rata populasi imago $O$. rhinoceros L. tiap perlakuan dengan menggunakan analisis kuantitatif sederhana:

$$
\mu=\frac{\sum x_{i}}{n}
$$


dimana: $\mu=$ Rata-rata populasi imago $O$. rhinoceros $\mathrm{L}$. tiap perlakuan (ekor), $x_{i}=$ Jumlah kumbang yang tertangkap per ulangan (ekor), $n=$ Banyaknya ulangan.

\section{HASIL DAN PEMBAHASAN}

Jumlah Tangkapan Imago Kumbang Tanduk ( $O$. rhinoceros L.) Tiap Perlakuan

Dari hasil pengamatan selama dua bulan, jumlah tangkapan $O$. rhinoceros L. tiap perlakuan dapat dilihat pada Gambar 1. Jumlah tangkapan imago O. rhinoceros L. terbanyak terdapat pada perlakuan perangkap dengan feromon yaitu 36 ekor dengan rerata populasi imago terperangkap 4,5 ekor/bulan. Diikuti berturut-turut perlakuan perangkap dengan feromon dan lampu $(2,375$ ekor/bulan) dan perlakuan perangkap dengan lampu (0,75 ekor/bulan).

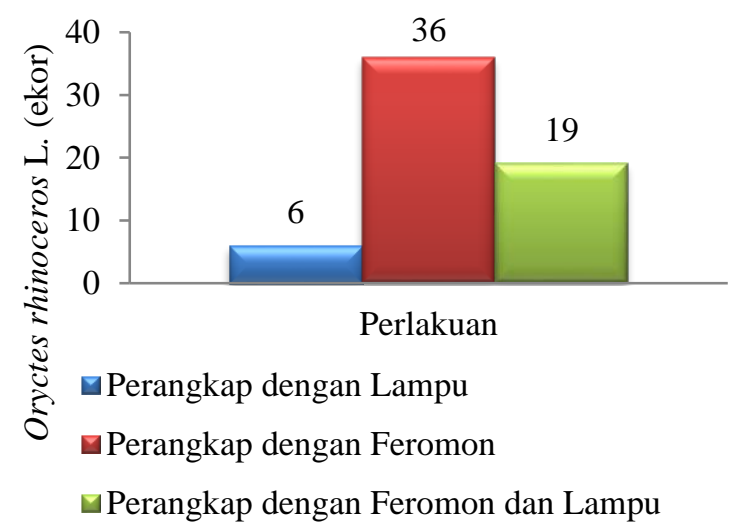

Gambar 1. Jumlah Tangkapan Imago O. rhinoceros L. Tiap Perlakuan.

Rerata tangkapan imago $O$. rhinoceros $\mathrm{L}$. terbanyak yakni 4,5 ekor/bulan, hal ini dikarenakan intensitas kerusakan pada lokasi pengamatan masuk dalam kategori ringan yakni antara 13,33-16,66\%. Alouw (2007), menyatakan pada lokasi dengan tingkat serangan ringan dengan penggunaan feromon rerata kumbang yang tertangkap adalah 5,6 ekor/ha/bulan sedangkan pada lokasi dengan tingkat kerusakan berat mencapai 27 ekor/ha/bulan.

Jenis perlakuan perangkap dengan feromon, memerangkap imago $O$. rhinoceros L. dengan jumlah terbanyak (36 ekor) dibandingkan perangkap dengan lampu dan perangkap dengan feromon dan lampu. Hal ini dikarenakan feromon sintetik (ethyl 4methyloctanoate) yang digunakan pada perangkap merupakan jenis feromon agregasi. Feromon agregasi merupakan bahan kimia yang dikeluarkan oleh serangga untuk menarik serangga jantan dan betina untuk berkumpul, untuk mencari pasangan dan dilanjutkan dengan kopulasi, mempertahankan diri terhadap serangan predator dan untuk mengatasi resistensi tanaman inang dengan jalan menyerang secara massal (Oka, 1998). Penggunaan feromon agregasi sintetik dapat menarik serangga jantan dan betina menuju ke perangkap. Feromon agregasi sintetik (ethyl 4methyloctanoate) ini memiliki tingkat keampuhan dalam memerangkap O. rhinoceros L. mencapai $95 \%$ (Widyanto et al., 2014).

Jenis perlakuan perangkap dengan feromon dan lampu memerangkap imago $O$. rhinoceros L. dengan jumlah yang sedang (19 ekor) sedangkan perlakuan perangkap dengan lampu memerangkap imago $O$. rhinoceros L. dengan jumlah yang paling sedikit (6 ekor). Rendahnya jumlah imago $O$. rhinoceros L. yang terperangkap pada kedua jenis perlakuan ini diduga disebabkan oleh penggunaan jenis lampu.

Karakteristik yang paling penting yang mempengaruhi daya tarik lampu terhadap serangga adalah perbedaan panjang gelombang, saturasi warna dan kecerahan cahaya (Longcore et al., 2015). Umumnya serangga nokturnal tertarik terhadap sumber cahaya yang memancarkan radiasi ultaviolet (UV) dengan jumlah yang relatif besar (Shimoda dan Honda, 2013). Perlakuan perangkap dengan feromon dan lampu serta perlakuan perangkap dengan lampu, menggunakan jenis lampu pijar (chiyoda 40 watt). Bola lampu pijar memancarkan cahaya paling kuat pada spektrum inframerah $(770 \mathrm{~nm}-1 \mathrm{~mm})$ dan lemah pada spektrum cahaya tampak (400-700 nm) dan spektrum ultraviolet (100-400 nm) (Cohnstaedt et al., 2008). Lemahnya spektrum ultraviolet yang dipancarkan oleh lampu pijar diduga menyebabkan penurunan daya tarik dari lampu tersebut terhadap serangga. Penurunan daya tarik lampu terhadap imago $O$. rhinoceros L. terlihat jelas pada perlakuan perangkap dengan lampu. Perlakuan perangkap dengan lampu memerangkap imago $O$. rhinoceros L. dengan jumlah yang paling sedikit (6 ekor), jika dibandingkan perlakuan perangkap dengan feromon dan lampu (19 ekor).

Peletakan perangkap yang berdekatan dengan pemukiman diduga juga mempengaruhi jumlah tangkapan $O$. rhinoceros $\mathrm{L}$, terlihat dengan masih ditemukannya imago $O$. rhinoceros L. pada rumah warga yang berdekatan dengan tempat peletakan perangkap. Hal ini diduga karena adanya persaingan kecerahan lampu (lampu rumah, lampu jalan dengan lampu pada perlakuan). Efisiensi konversi arus listrik ke cahaya atau disebut efikasi luminus dari lampu pijar sangatlah rendah sekitar $6 \%$ dan sisanya $94 \%$ dipancarkan sebagai radiasi atau panas inframerah (Cohnstaedt et al., 2008).

Besarnya radiasi atau panas inframerah (94\%) yang dipancarkan oleh lampu pijar diduga mempengaruhi daya kerja feromon agregasi sintetik yang dipasang pada perlakuan perangkap dengan feromon dan lampu sehingga ketika dikombinasikan (feromon dan lampu), perlakuan ini menjadi kurang efektif terhadap $O$. rhinoceros L.. Alouw (2007) mengatakan keberhasilan penggunaan feromon dipengaruhi oleh penguapan bahan kimia, kepekaan penerima, jumlah dan bahan kimia yang dihasilkan dan dibebaskan persatuan waktu, kecepatan angin dan temperatur. Peletakan lampu tepat diatas ember plastik diduga menyebabkan suhu didalam ember plastik menjadi lebih tinggi sehingga feromon akan 
menguap lebih cepat, mudah habis dan tidak bertahan lama dilapangan, jika dibandingkan dengan feromon pada perlakuan perangkap dengan feromon saja. Dari hasil penelitian ini maka hipotesis yang diajukan ditolak karena tidak terbukti.

Selama dua bulan pengamatan hasil tangkapan imago $O$. rhinoceros $\mathrm{L}$. tiap perlakuan mengalami fluktuasi. Hasil tangkapan tertinggi imago $O$. rhinoceros L. yakni pada jenis perangkap dengan feromon minggu ke-4 yang mencapai hasil sebanyak 10 ekor (Gambar 2).

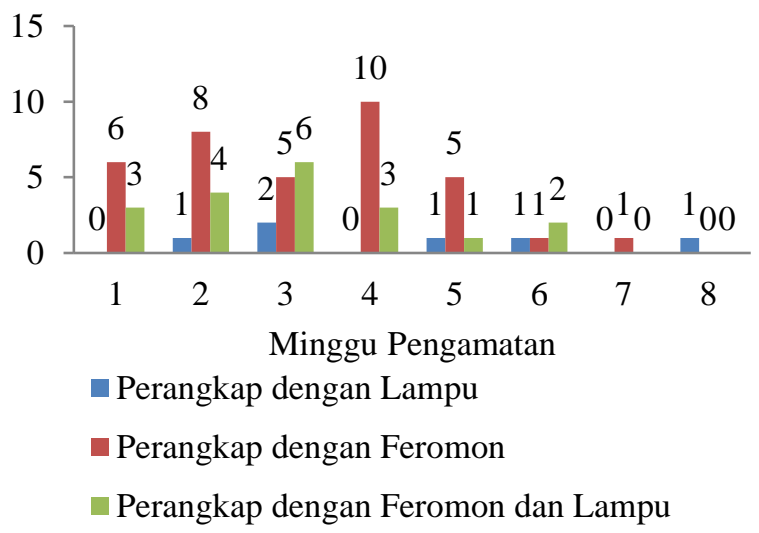

Gambar 2. Jumlah Tangkapan Imago O. rhinoceros L. Tiap Minggu Pengamatan

Jumlah imago $O$. rhinoceros L. yang terperangkap mengalami fluktuasi dan semakin lama semakin berkurang. Penurunan jumlah imago $O$. rhinoceros L. yang terperangkap signifikan terjadi pada jenis perlakuan perangkap dengan feromon dan perlakuan perangkap dengan feromon dan lampu. Hal ini disebabkan oleh penggunaan feromon yang berbentuk cair akan berkurang kuantitasnya akibat penguapan, sehingga bau (senyawa kimia) dari feromon perlahanlahan akan hilang dan tidak berpengaruh lagi pada imago O. rhinoceros L.. Widyanto et al. (2014) menyatakan senyawa kimia etil 4-methylactonoat pada feromon agregasi sintetik hanya mampu bertahan selama tiga bulan di lapangan, jika disimpan terlalu lama akan habis menguap. Berkurangnya populasi imago O. rhinoceros L. pada areal pengamatan juga sangat mempengaruhi jumlah tangkapan imago $O$. rhinoceros L. tiap minggunya. Sedangkan pada perlakuan perangkap dengan lampu tidak mengalami perubahan yang signifikan, hal ini dikarenakan penggunaan lampu selama dua bulan pengamatan kurang atau tidak mengalami perubahan daya penyinaran.

Dalam penelitian ini faktor suhu dan kelembaban kurang berpengaruh terhadap penyebaran serangga. Hasil pengamatan rata-rata suhu dan kelembaban selama penelitian adalah sebagai berikut: rata-rata suhu $26,67^{\circ} \mathrm{C}$ dan rata-rata kelembaban $82,85 \%$. Dapat dikatakan bahwa suhu dan kelembaban sangat mendukung terhadap aktivitas serangga. Kondisi optimum suhu dan kelembaban untuk perkembangan dan aktivitas serangga adalah $25^{\circ} \mathrm{C}$ dan kelembaban 70-89\% (Jumar, 2000).
Jumlah Tangkapan Imago Kumbang Tanduk ( $O$. rhinoceros L.) Jantan Dan Betina Tiap Perlakuan

Dari hasil pengamatan selama dua bulan di laboratorium, perbandingan tangkapan imago $O$. rhinoceros L. tiap perlakuan dapat dilihat pada Gambar 3.

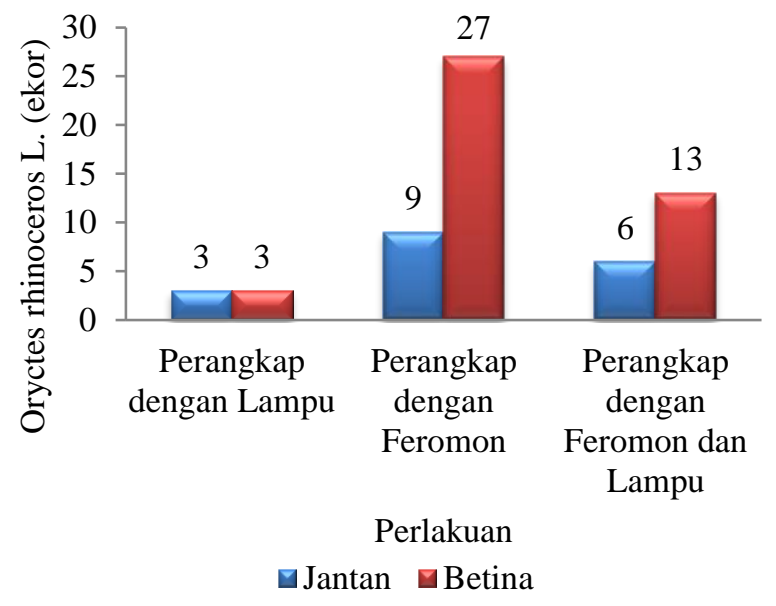

Gambar 3. Jumlah Tangkapan Imago O. rhinoceros L. Jantan dan Betina Tiap Perlakuan

Jenis perlakuan perangkap dengan feromon dan perlakuan perangkap dengan feromon dan lampu merupakan jenis perlakuan yang menggunakan feromon agregasi sintetik (Ethyl 4-methyloctanoate). Kedua jenis perlakuan ini memerangkap imago $O$. rhinoceros L. betina dengan jumlah lebih banyak dibandingkan imago O. rhinoceros L. jantan. Perbandingan tangkapan imago O. rhinoceros L. betina terhadap jantan dari kedua jenis perlakuan ini yakni 27 ekor : 9 ekor $(75 \%: 25 \%)$ dan 13 ekor : 6 ekor $(68,4 \%$ : 31,6 \%). Sahetapy (2001) menyatakan faktor penentu respons serangga terhadap senyawa feromon yang dilepaskan oleh lawan jenisnya adalah pada kuantitas dan kualitas campuran (blend) bahan kimianya. Campuran (blend) dari feromon agregasi sintetik ini dibuat berdasarkan senyawa kimia ethyl 4-methyloctanoate. Ethyl 4-methyloctanoate merupakan senyawa feromon yang dihasilkan oleh imago O. rhinoceros L. jantan (Hallett et al., 1995; Morin et al., 1996). Campuran (blend) dari feromon agregasi sintetik inilah yang diduga menyebabkan imago betina lebih banyak terperangkap, karena imago betina mengenali molekul-molekul dari feromon agregasi sintetik ini dan meresponsnya dengan mencari asal dari bau feromon tersebut. Hal ini diperkuat oleh Santi dan Sumaryo (2008) yang menyatakan feromon agregasi sintetik (Ethyl 4-methyloctanoate) menarik 69-79\% imago betina dan imago jantan hanya 21-31\%. Sedangkan jenis perangkap dengan lampu memerangkap imago $O$. rhinoceros $\mathrm{L}$. jantan dan betina dengan jumlah yang sama 3 ekor : 3 ekor (50\%: 50\%). Hal ini dikarenakan imago $O$. rhinoceros L. jantan dan betina merupakan serangga noktunal yang sama-sama memiliki ketertarikan terhadap cahaya. 
Dari hasil pengamatan di laboratorium, ciri-ciri membedakan imago $O$. rhinoceros L. jantan dan imago $O$. rhinoceros $\mathrm{L}$. betina yakni imago $O$. rhinoceros $\mathrm{L}$. jantan memiliki tanduk yang lebih panjang dibandingkan imago O. rhinoceros L. betina (Gambar 4), ciri lainnya pada pygidium (ujung abdomen) imago $O$. rhinoceros L. jantan ditumbuhi bulu dengan jumlah yang sedikit dibandingkan dengan imago $O$. rhinoceros L. betina yang ditumbuhi bulu lebat berwarna coklat kemerahmerahan (Gambar 5). Hal ini sesuai dengan pendapat Menon et al. (1958) dan Kalshoven (1981), yang menyatakan imago jantan dapat dibedakan dari betina oleh adanya tanduk yang panjang, dan imago betina memiliki bulu yang lebat berwarna coklat kemerahmerahan pada pygidium.

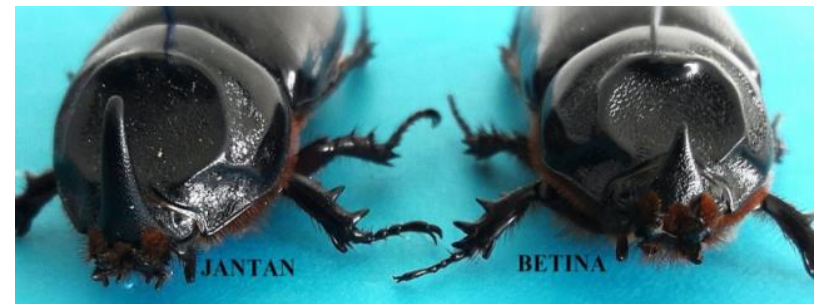

Gambar 4. Ciri Tanduk pada Imago O. rhinoceros L. Jantan dan Betina

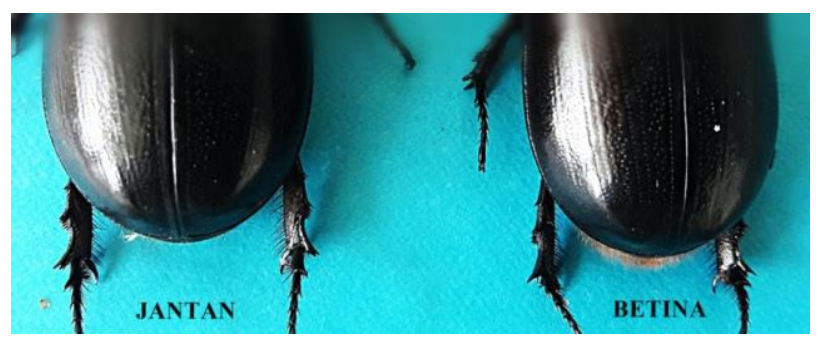

Gambar 5. Ciri Bulu pada Pygidium Imago $O$. rhinoceros L. Jantan dan Betina

Berkurangnya populasi imago $O$. rhinoceros L. betina akibat penggunaan perangkap feromon di lapangan diduga dapat mengakibatkan penurunan populasi $O$. rhinoceros L. pada generasi berikutnya, hal ini disebabkan oleh adanya perubahan laju kelahiran. Salah satu faktor utama penentu laju kelahiran adalah sex ratio. Sex ratio pada populasi serangga umumnya adalah 1:1, jantan terhadap betina (Hadi et al., 2009). Namun dengan penggunaan feromon terjadi perubahan sex ratio di lapangan yakni menjadi 2:1 atau 3:1 jantan terhadap betina, dikarenakan feromon menarik $69-79 \%$ imago betina sedangkan imago jantan hanya 21-31\%. Berkurangnya individu imago $O$. rhinoceros L. betina di lapangan diduga menyebabkan terjadinya gangguan pada proses kopulasi (perkawinan serangga), akibatnya kelahiran individu $O$. rhinoceros L. baru akan terganggu atau mengalami penurunan. Hadi et al. (2009), menyatakan bahwa dengan adanya perubahan proposi imago betina dilapangan menyebabkan perubahan laju kelahiran.

\section{KESIMPULAN}

Jenis perangkap yang paling efektif terhadap kumbang tanduk (O. rhinoceros L.) adalah perangkap dengan feromon.

\section{DAFTAR PUSTAKA}

Alouw J.C. 2007. Feromon dan Pemanfaatannya dalam Penengalian Hama Kumbang Kelapa Oryctes rhinoceros (Coleoptera: Scarabaeidae). Balai Peneletian Kalapa dan Palma Lain, Buletin Palma 32: 12-21.

Badan Pusat Statistik, 2016. Maluku Dalam Angka Tahun 2016.

Bedford, G.O. 2014. Advances in the control of Rhinoceros Beetle, Oryctes rhinoceros in oil palm. Journal of Oil Palm Reseach 26: 183-194.

Cohnstaedt, L., J.I. Gillen, and L.E. Munstermann. 2008. Light-emitting diode technology improves insect trapping. Journal of the American Mosquito Control Association 24: 331-334.

Direktorat Jendral Pekebunan. 2015. Statistik Pekebunan Kelapa Tree Crop Estate Statisties Of Indonesia 2014-2016.

Hadi, M.H., U. Tarwotjo, dan R. Rahadian. 2009. Biologi Insekta Entolomogi. Graha Ilmu. Yogyakarta. $162 \mathrm{p}$.

Hallett, R.H., A.L. Perez, G. Gries, R. Gries, H.D. Pierce Jr., J. Yue, A.C. Oehlschlager, L.M. Gonzalez, and J.H. Borden. 1995. Aggregation pheromone of the coconut rhinoceos beetle, Oryctes rhinoceros L. (Coleoptera: Scarabaeidae). Journal of Chemical Ecology 21: 1549-1570.

Hosang. M.L.A dan Salim. 2014. Penekanan Populasi Oryctes rhinoceros dan Rhynchophorus ferrugineus dengan perangkap feromon. Balai Penelitian Tanaman Kelapa dan Palma Lain. Prosiding Konferensi Nasional Kelapa VII. 21-22 Mei 2014, Jambi, Indonesia. pp 65-72.

Jumar. 2000. Entomologi Petanian. Rineka Cipta. Jakarta. 237 p.

Kalshoven, L.G.E. 1981. The pest of crops in Indonesia. Revised by P.A. Van der Laan. P.T. Ichtiar BaruVan Hoeve. Jakarta. pp 463-468.

Kartasapoetra, A.G. 1993. Hama Tanaman Pangan dan Perkebunan. Bumi Aksara. Jakarta. pp 165-168.

Lekahena, R. 2013. Pengenalan dan pengendalian hama Oryctes sp dengan jamur Metharizium anisopliae, BBPPTP Ambon Direktorat Jendral Perkebunan Kementerian Pertanian. http://ditjenbun.petanian. go.id/bbpptpambon/ berita-188-pengenalan-danpengendalian-hama-oryctes-sp-dengan-jamur-

metharizium-anisopliae.html. Diakses: 06 Agustus 2016.

Longcore, T., H.L. Aldern, J.F. Eggers, S. Flores, L. Franco, E.H. Yamanishi, L.N. Petrinec, W.A. Yan, and A.D. Barroso. 2015. Tuning the white light spectrum of light emitting diode lamps to reduce attraction of nocturnal arthropods. 
Philosophical Transactions of the Royal Society B Biological Sciences 370.

Menon, K.P.V. and K.M. Pandalai. 1958. The Cocount Palm A Monograph. Indian Central Coconut Committee. India. pp 251-253.

Morin, J.P., D. Rochat, C. Malosse, M. Lettee, R. Desmier de Chenon, H. Wiwbo, and C. Descoins. 1996. Ethyl 4-methyloctanoate, major component of male pheromone in Oryctes rhinoceros (L.) (Coleoptera, Dynastidae). Journals Comptes Rendus De l'Academic Sciences 319: 595-602.

Oka, I.N. 1998. Pengendalian Hama Terpadu dan Implementasinya di Indonesia. Gadjah Mada University Press. Yogyakarta. pp 172-176.

Sahetapy, B. 2001. Kajian Daya Tarik Ekstrak Feromon Seks Nezara viridula (Hemiptera: Pentatomidae) di Laboratorium. Tesis. Yogyakarta: Program Pasca Sarjana, Universitas Gadjah Mada. pp 8-10.

Santi, I.D., dan B. Sumaryo. 2008. Pengaruh warna perangkap feromon terhadap hasil tangkapan imago Oryctes rhinoceros di perkebunan kelapa sawit. Jurnal Perlindungan Tanaman Indonesia 14: 76-79.
Shimoda, M. and Honda, K. 2013. Insect reactions to light and its applications to pest management. Applied Entomology and Zoologi 48: 413-421.

Setyamidjaja, D. 2000. Bertanam Kelapa. Kanisius. Yogyakarta. $120 \mathrm{p}$.

Untung, K. 1993. Pengantar Pengelolaan Hama Terpadu. Gadjah Mada University Press. Yogyakarta. $273 \mathrm{p}$.

Wibawanti, R. 2013. Upaya Pengendalian Kumbang Kelapa (Oryctes rhinoceros) di Yogyakarta, Direktorat Jendral Perkebunan Kementerian Pertanian. Yogyakarta.

Widyanto, H., S. Saputra dan Suryati. 2014. Pengendalian Hama Kumbang Tanduk (Oryctes rhinoceros Linn) mengggunakan perangkap feromon pada tanaman kelapa sawit (Elaeis Guineensis Jacq) di lahan gambut provinsi riau. Prosiding Seminar Nasional Pengelolaan Berkelanjutan Lahan Gambut Terdegradasi Untuk Mitiggasi Emisi GRK dan Peningkatan Nilai Ekonomi. 18-19 Agusatus, Jakarta, Indonesia. pp 195-204.

Winarno, B. 1992. Pengantar Praktis Pengendalian Hama Terpadu. Yayasan Pembina Fakultas Pertanian Univesitas Brawijaya. Malang. 81 p. 